\title{
Assessing the viability of cryopreserved coconut zygotic embryos by electrolytic conductivity and potassium leaching
}

\author{
Kicia Karinne Pereira Gomes-Copeland(1), Ana da Silva Lédo(2), Fabrício Tavares Cunha de Almeida(1), \\ Roberta Pereira Miranda ${ }^{(1)}$ and Izulmé Rita Imaculada Santos ${ }^{(3)}$
}

\begin{abstract}
(1)Universidade Federal de Sergipe, Avenida Marechal Rondon, s/no, Jardim Rosa Elze, CEP 49100-000 São Cristovão, SE, Brazil. E-mail: kiciagomes@yahoo.com.br, fabriciohidrogenio@yahoo.com.br, romiranda_fernandes@yahoo.com.br (2)Embrapa Tabuleiros Costeiros, Avenida Beira Mar, № 3.250, CEP 49025-040 Aracaju, SE, Brazil. E-mail: analedo@cpatc.embrapa.br (3)Embrapa Recursos Genéticos e Biotecnologia, Avenida W5 Norte (Final), CEP 70770-917 Brasília, DF, Brazil. E-mail: izulme@cenargen.embrapa.br
\end{abstract}

\begin{abstract}
The objective of this work was to adapt the application of electrolytic conductivity and potassium leaching tests to assess the viability of cryopreserved embryos of 'Anão Verde do Brasil de Jiqui' (AVeJBr) coconut. The zygotic embryos were excised, sterilized and subjected to four cryoprotectant treatments combined with three incubation times (12,16 and 20 hours), totaling 12 treatments. The pre-treatment of mature zygotic embryos of AVeJBr coconut using a cryoprotectant with $1.75 \mathrm{~mol} \mathrm{~L}^{-1}$ of sucrose $+15 \%$ glycerol for 12 and 16 hours promoted lower embryo humidity and increased viability in electrolytic conductivity and potassium leaching tests. Samples with ten embryos are sufficient for electrolytic conductivity analysis in cryopreserved or non-cryopreserved AVeJBr coconut zygotic embryos. The 4 to 8 hour imbibition period of the embryos is promising for the electrolytic conductivity analysis of non-cryopreserved mature zygotic embryos of $\mathrm{AVeJBr}$ coconut.
\end{abstract}

Index terms: Cocos nucifera, biochemistry, cell membrane, cryoprotectant, genetic resources.

\section{Avaliação da viabilidade de embriões de coqueiro criopreservados por meio de condutividade elétrica e lixiviação de potássio}

\begin{abstract}
Resumo - O objetivo deste trabalho foi adaptar a aplicação de testes de condutividade elétrica e lixiviação de potássio para avaliar a viabilidade de embriões de coqueiro 'Anão Verde do Brasil de Jiqui' (AVeJBr) criopreservados. Os embriões zigóticos foram excisados, esterilizados e submetidos a quatro tratamentos crioprotetores combinados a três tempos de incubação (12, 16 e 20 horas), o que totalizou 12 tratamentos. O pré-tratamento de embriões zigóticos maduros de coco AVeJBr com crioprotetor contendo $1,75 \mathrm{~mol} \mathrm{~L}^{-1}$ de sacarose $+15 \%$ de glicerol por 12 e 16 horas promoveu menor umidade dos embriões e maior viabilidade em testes de condutividade elétrica e lixiviação de potássio. Amostras com dez embriões são suficientes para análise de condutividade elétrica em embriões zigóticos de coqueiro $\mathrm{AVeJBr}$ criopreservados ou não. O período de embebição de 4 a 8 horas é promissor para a análise da condutividade elétrica em embriões zigóticos maduros de coco $\mathrm{AVeJBr}$ não criopreservados.
\end{abstract}

Termos para indexação: Cocos nucifera, bioquímica, membrana celular, crioprotetor, recursos genéticos.

\section{Introduction}

In Brazil, coconut (Cocos nucifera L.) is cultivated mainly along the coast, from the state of Pará to Espírito Santo. The country is currently the fourth largest coconut producer, and the Northeast is the region that concentrates most of the production.

The conservation of coconut genetic resources is done mainly in field collections, due to the size of the seed and because the seed is recalcitrant, which makes it difficult to store (N'nan et al., 2008). The conservation of coconut genetic resources has been a priority for the development of conservation programs, since 1985, by Bioversity International, originally established as the International Board for Plant Genetic Resources.

Cryopreservation has been used for the conservation of genetic resources in many species, especially recalcitrant ones, such as coconut (Hornung et al., 2001; N'nan et al., 2008). Early studies of cryopreservation with coconut were carried out by Assy-Bah \& Engelmann (1992), who used the vitrification technique in mature zygotic embryos of the coconut hybrid PB121 ('Malayan Yellow Dwarf' x 'West African Tall'), 'Cameroon Red Dwarf' (CRD), 'Indian Tall' (IT7) and 
'Rennel Tall' (RT). Later, other researchers, such as Karun et al. (2005, 2006), Malaurie et al. (2006, 2011), Sajini et al. (2006), Bandupriya et al. (2007), N'Nan et al. (2008), Sisunandar et al. (2010), among others, published promising results with cryopreservation using zygotic embryos, plumules and pollen as explants.

Plant cells have a high amount of intra- and extracellular water, and, therefore, are extremely sensitive to sub-zero temperatures due to the formation of ice crystals. Intracellular crystallization causes the rupture of the cell membrane system, which can also be caused by extreme dehydration (Santos \& Salomão, 2007). Cryopreservation techniques have been developed to minimize both types of damage (Reed, 2008).

The capacity of plant tissues to survive cryopreservation depends on their tolerance to dehydration and to low temperatures, since these factors can irreversibly affect the cell membrane, resulting in tissue death. The membranes are formed by a double layer of phospholipids, which are in a liquid crystalline state at physiological temperature, but turn into a gel state, which is reversible after rehydration, when water is removed from this layer. However, this change of lipid behavior can be detrimental to the membrane organization, since it contributes to the loss of permeability, to compartmentalization and to linked enzyme activity (Crowe et al., 1988).

Changes in the structural integrity and functionality of the membrane caused by water stress may be indicated by the leakage of various cytoplasm components $\left(\mathrm{Ca}^{2+}\right.$, $\mathrm{K}^{+}, \mathrm{Mg}^{2+}$ and $\mathrm{Na}^{+}$ions; sugars and proteins), which occurs after the rehydration process (Santos, 2000), promoting partial loss of membrane permeability.

Therefore, biochemical and physiological studies related to water and osmotic stress are important to predict the potential damage to the membrane and to reduce costs of large experiments. Rapid response tests, such as electrolytic conductivity and potassium leaching, which are widely used in seeds, may be promising if adapted to analyze the viability of seeds as explants and of cryopreserved zygotic embryos.

The electrolytic conductivity is based on determining the concentration of electrolytes leached into solution, which is directly related to the integrity of cell membranes, indicating the level of seed damage. During the seed maturation process, morphological, physiological, biochemical and functional changes occur, especially regarding membrane development, which, when under stress, is the first to show signs of deterioration (Vieira, 1994). According to Best (2010), for animal cells, the analysis of $\mathrm{Na}^{+}$and $\mathrm{K}^{+}$ are the first steps to test cryoprotectant efficiency after cryopreservation. Martins et al. (2009) found electrolytic conductivity tests promising in assessing the quality of assai (Euterpe oleracea Mart.) seeds.

However, there is no known literature on the efficiency of cryoprotectants on assessing the viability of cryopreserved species by electrolytic conductivity and potassium leaching tests. Therefore, studies on the adaptation and evaluation of these tests for cryopreservation are fundamental.

The objective of this work was to adapt the application of electrolytic conductivity and potassium leaching tests to assess the viability of cryopreserved embryos of 'Anão Verde do Brasil de Jiqui' (AVeJBr) coconut.

\section{Materials and Methods}

The source material used in the experiment was obtained from a commercial plantation of $\mathrm{AVeJBr}$ coconut located at the farm H. Dantas - Coco Verde de Sergipe, Neópolis, SE, Brazil (10²2'53"S and $36^{\circ} 44^{\prime} 0^{\prime \prime} \mathrm{W}$, at 127 meters above sea level). The climate of the region, according to Köppen, is tropical rainy with dry summer.

Coconut plants, undersix years of age, were planted on Udic Kandiustalf, with medium to low fertility, using a microaspersion irrigation system. Endosperm cylinders with zygotic embryos extracted from 750 mature fruits, collected from 30 plants, were immersed in $2.0-2.5 \%$ commercial sodium hypochlorite and washed in sterile water three times at the collection site. The embryos were then placed in sterile containers and sent to the laboratory for plant tissue culture of Embrapa Tabuleiros Costeiros, Aracaju, SE, Brazil. Under aseptic conditions, embryos were excised from the endosperm cylinders and immersed in $70 \%$ ethyl alcohol for $2 \mathrm{~min}$ and in a commercial solution of sodium hypochlorite $\left(1 \%, \mathrm{v} \mathrm{v}^{-1}\right)$ for $3 \mathrm{~min}$, shaken and then washed three times in sterile distilled water and placed in sterile Petri dishes. The germination capacity of each embryo sample was evaluated in Y3 liquid medium (Eeuwens, 1976) in a growth chamber, in the 
absence of light, at $24 \pm 2^{\circ} \mathrm{C}$ after 50 days a germination of $100 \%$ was observed.

Electrolytic conductance was determined before the immersion in liquid nitrogen of early embryos excised from fruits (non-cryopreserved embryos) in order to define the optimal deionized water incubation time and the sample size needed for the test. Five incubation times were tested: 4, 8, 12, 24 and 36 hours with 10, 20 and 30 mature zygotic embryos, with three replicates for each treatment, totaling 180 embryos.

The embryos were soaked in plastic cups $(200 \mathrm{~mL}$ capacity) containing $80 \mathrm{~mL}$ of deionized water and were kept in BOD at constant temperature of $20^{\circ} \mathrm{C}$. After each period, electrolytic conductivity was measured with a bench conductivity meter, model CON510 (Oakton Instruments, Vernon Hills, IL, USA), and the results were expressed in microseconds (Vieira, 1994). The fresh sample mass was determined after each conductivity measurement in analytical balance, model SA80 (Scientech, Boulder, CO, USA).

The cryopreserved embryos were inoculated in Y3 liquid culture medium with four different cryoprotectant pre-treatments: T1, $1.75 \mathrm{~mol} \mathrm{~L}^{-1}$ of sucrose $+15 \%$ glycerol; T2, $1.75 \mathrm{~mol} \mathrm{~L}^{-1}$ of glucose $+15 \%$ glycerol (Assy-Bah \& Engelmann, 1992); T3, $1.75 \mathrm{~mol} \mathrm{~L}^{-1}$ of sucrose; and T4, $1.75 \mathrm{~mol} \mathrm{~L}^{-1}$ of glucose. The cultures were maintained on an orbital shaking-table at $100 \mathrm{rpm}$ for 12,16 and 20 hours in the cryoprotectant solution, totaling 12 treatments and 120 embryos. The embryos were then dried for 4 hours in silica gel at room temperature. After this period, the embryo samples were placed in Petri dishes with filter paper to remove excess culture medium and were weighed to determine fresh embryo weight (WF). The embryos were placed in metal containers and were kept at $105^{\circ} \mathrm{C}$ for 18 hours to determine dry embryo weight (WD). The moisture content (MC) of the embryos was determined using the following formula: $\% \mathrm{MC}=(\mathrm{WF}-\mathrm{WD}) / \mathrm{WF} \times 100$ (Horwitz, 2005).

For cryopreservation, the embryos were kept on cryovials in liquid nitrogen at $-196^{\circ} \mathrm{C}$ for 48 hours. After cryopreservation, the cryovials containing the embryos were immediately immersed in a water bath at $40^{\circ} \mathrm{C}$ for $5 \mathrm{~min}$. Electrolytic conductivity was measured as previously described in samples from each treatment with ten embryos. The results were expressed in $\mu \mathrm{S} \mathrm{cm}^{-1}$.
To determine the best sample size for the quantification of potassium leached through the membrane, samples of 10, 20 and 30 mature zygotic embryos, in triplicate, totaling 180 embryos, were used. The embryos were soaked in $200-\mathrm{mL}$ plastic cups containing $80 \mathrm{~mL}$ of deionized water and were kept in BOD at constant temperature of $20^{\circ} \mathrm{C}$ (Vieira, 1994). After 24 hours of incubation in deionized water, aliquots of $2.5 \mathrm{~mL}$ of each exudate were removed and diluted in $25 \mathrm{~mL}$ of deionized water to determine the amount of potassium leached using an atomic absorption spectrometer, model SpectrAA 55B (Agilent Technologies, Santa Clara, CA, USA), according to the methodology proposed by Souza et al. (2009), with modifications. The results were expressed in $\mathrm{mg} \mathrm{L}^{-1}$ of potassium.

Potassium leaching was measured in the zygotic embryo exudates previously subjected to the four pre-treatments with cryoprotectants combined with 12 , 16 and 20-hour incubation times.

After cryopreservation, the cryovials containing the embryos were immediately immersed in a water bath at $40^{\circ} \mathrm{C}$ for $5 \mathrm{~min}$. Potassium leaching was measured as previously described for samples with ten embryos. The results were expressed in $\mathrm{mg} \mathrm{L}^{-1}$ of potassium.

The descriptive statistical averages and the standard deviation were calculated with the GraphPad Prism 3.0 software (Graphpad Software, San Diego, CA, USA) for all descriptive values.

\section{Results and Discussion}

Tests for electrolytic conductivity indicated an almost proportional increase among the three sample sizes of coconut embryos (Table 1), with an increase in conductance with increasing sample size. The electrolytic conductivity for the ten-embryo sample size proved to be adequate to differentiate incubation times and was selected for further testing, having enough sensitivity to be read by a conductivimeter. It is important to note that, in the present study, the conductivity test was applied to zygotic embryos excised from seeds and not to whole seeds, differently from researches with other species, using larger samples with a greater number of seeds, such as Martins et al. (2009), who evaluated 25 assai palm seeds.

Embryo weight increased gradually with time in all samples during incubation, and stability was not observed during the 36-hour monitoring period. 
According to Vanzolini \& Nakagawa (1999), early in the incubation process, there is a rapid and intense release of electrolytes to reach an equilibrium point, when the cell membranes reorganize themselves. Therefore, the maximum time of 36 hours was probably not enough to achieve this balance, due to the size of the coconut embryos.

As no stability was observed for water absorption, further studies need to be carried out to assess the integrity of the membranes of coconut cryopreserved embryos in order to define the most appropriate incubation times for conductivity tests.

Regarding incubation time, the lowest conductivity was observed during the first 4-hour period for the ten-embryo sample, which tripled by the $36^{\text {th }}$ hour. The electrolytic conductivity values for the samples of 20 and 30 embryos were nearly proportional to those obtained for the ten-embryo sample (Table 1).

The period of 4 to 8 hours of imbibition can be considered promising for conductivity analysis in coconut zygotic embryos with low values. Vieira (1994) reported that the lower the electrolyte leakage, the lower the possibility of damage to the cell membrane and, consequently, the lower the conductivity. Souza et al. (2009) concluded that from 6 hours of incubation it was possible to separate batches of two castor bean cultivars, with significant reduction in the incubation period of the seed in comparison to the 24-hour period, which is adopted as a standard for most species.

To evaluate the conductivity of the cryopreserved embryos, a 24-hour incubation period was considered (Vieira, 1994), using a ten-embryo sample size. The treatments with $1.75 \mathrm{~mol} \mathrm{~L}^{-1}$ of sucrose $+15 \%$ glycerol for 12 and 16 hours (12hT1 and 16hT1) showed an electrolytic conductivity of 270 and $265 \mu \mathrm{S} \mathrm{cm} \mathrm{cm}^{-1}$, respectively, which was low when compared to the other treatments (Figure 1). The lowest percentage of moisture in the embryos (26.63 \pm 0.74 and $23.48 \pm 1.94$, respectively) was also observed for this treatment, which is an optimal condition for zygotic embryo cryopreservation (Table 2).

Martins et al. (2009) assessed the relative quality between samples of assai palm as a common problem for quality testing of native seeds and cultivated species, but reference values are lacking. However, Vieira (1994) reported lower electrolytic conductivity resulting from a lower leaching of solutes and, consequently, a smaller destruction of cell membranes, accounting for the maintenance of vitality. Souza et al. (2009), while evaluating castor bean (cultivar IAC 80), found intense leaching of electrolytes at the beginning of the conductivity test, which was more evident in the seed lots with low physiological quality.

Leaching of $\mathrm{K}^{+}$ions was evaluated after measuring the electrolytic conductivity from 24 hours of incubation on deionized water, and less leaching was observed in embryos of treatments $12 \mathrm{hT} 1$ and 16hT1 (Figure 1). This supports the results obtained for electrolytic conductivity for the same treatments and probably indicates the occurrence of less damage to the cell membranes. It is important to stress that the values of potassium ion leaching are much lower than those of electrolytic conductivity, since the conductivity of various electrolytes, such as $\mathrm{Na}^{+}$and $\mathrm{Mg}^{2+}$, contribute to higher conductance values.

However, further studies on electrolytic conductivity are required to better indicate the application of conductivity tests for the analysis of the physiological quality of cryopreserved coconut.

Table 1. Fresh weight and electrolytic conductivity of non-cryopreserved embryos of 'Anão Verde do Brasil de Jiqui' coconut in relation to incubation time and sample size ${ }^{(1)}$.

\begin{tabular}{|c|c|c|c|c|c|c|c|c|c|}
\hline \multirow{3}{*}{$\begin{array}{l}\text { Time } \\
\text { (hour) }\end{array}$} & \multicolumn{3}{|c|}{10 embryos } & \multicolumn{3}{|c|}{20 embryos } & \multicolumn{3}{|c|}{30 embryos } \\
\hline & Individual & Total & Conductivity & Individual & Total & Conductivity & Individual & Total & Conductivity \\
\hline & \multicolumn{2}{|c|}{-------- (g) ------- } & $\left(\mu \mathrm{S} \mathrm{cm}^{-1}\right)$ & ---------- & ) -------- & $\left(\mu \mathrm{S} \mathrm{cm}^{-1}\right)$ & \multicolumn{2}{|c|}{------- (g) ------- } & $\left(\mu \mathrm{S} \mathrm{cm}^{-1}\right)$ \\
\hline 0 & 0.130 & $1.30 \pm 0.04$ & $3.83 \pm 0.00$ & 0.1270 & $2.55 \pm 0.01$ & $3.83 \pm 0.00$ & 0.131 & $3.93 \pm 0.13$ & $3.83 \pm 0.00$ \\
\hline 4 & 0.143 & $1.43 \pm 0.04$ & $56.13 \pm 0.43$ & 0.1400 & $2.79 \pm 0.01$ & $92.20 \pm 2.77$ & 0.145 & $4.34 \pm 0.14$ & $143.70 \pm 19.78$ \\
\hline 8 & 0.146 & $1.46 \pm 0.05$ & $86.93 \pm 0.04$ & 0.1420 & $2.85 \pm 0.01$ & $163.57 \pm 4.64$ & 0.147 & $4.41 \pm 0.12$ & $250.33 \pm 20.54$ \\
\hline 12 & 0.150 & $1.50 \pm 0.05$ & $106.23 \pm 2.19$ & 0.1465 & $2.93 \pm 0.02$ & $205.53 \pm 6.69$ & 0.152 & $4.55 \pm 0.12$ & $309.33 \pm 22.98$ \\
\hline 24 & 0.157 & $1.57 \pm 0.05$ & $147.00 \pm 5.54$ & 0.1495 & $2.99 \pm 0.04$ & $290.00 \pm 3.05$ & 0.157 & $4.71 \pm 0.13$ & $427.33 \pm 35.71$ \\
\hline 36 & 0.161 & $1.61 \pm 0.05$ & $169.27 \pm 11.20$ & 0.1535 & $3.07 \pm 0.05$ & $337.33 \pm 9.84$ & 0.161 & $4.84 \pm 0.13$ & $497.33 \pm 46.62$ \\
\hline
\end{tabular}

${ }^{(1)}$ Values represent the mean of three replicates \pm standard error of mean. 
Table 2. Moisture content of zygotic embryos of 'Anão Verde do Brasil de Jiqui' coconut in four cryoprotectant treatments combined with three incubation times of 12,16 and 20 hours $^{(1)}$.

\begin{tabular}{lcccc}
\hline Time (hour) & \multicolumn{4}{c}{ Moisture content (\%) } \\
\cline { 2 - 5 } & $\mathrm{T} 1$ & $\mathrm{~T} 2$ & $\mathrm{~T} 3$ & $\mathrm{~T} 4$ \\
\hline 12 & $26.63 \pm 0.74$ & $34.22 \pm 0.88$ & $30.70 \pm 4.39$ & $45.45 \pm 0.48$ \\
16 & $23.48 \pm 1.94$ & $31.07 \pm 0.64$ & $28.00 \pm 0.47$ & $43.17 \pm 1.78$ \\
20 & $31.87 \pm 3.96$ & $42.89 \pm 0.13$ & $44.16 \pm 11.57$ & $41.38 \pm 1.67$ \\
\hline
\end{tabular}

${ }^{(1)}$ Values represent the mean of three replicates \pm standard error of mean. T1, $1.75 \mathrm{~mol} \mathrm{~L}^{-1}$ of sucrose $+15 \%$ glycerol; T2, $1.75 \mathrm{~mol} \mathrm{~L}^{-1}$ of glucose $+15 \%$ glycerol; T3, $1.75 \mathrm{~mol} \mathrm{~L}^{-1}$ of sucrose; and T4, $1.75 \mathrm{~mol} \mathrm{~L}^{-1}$ of glucose.

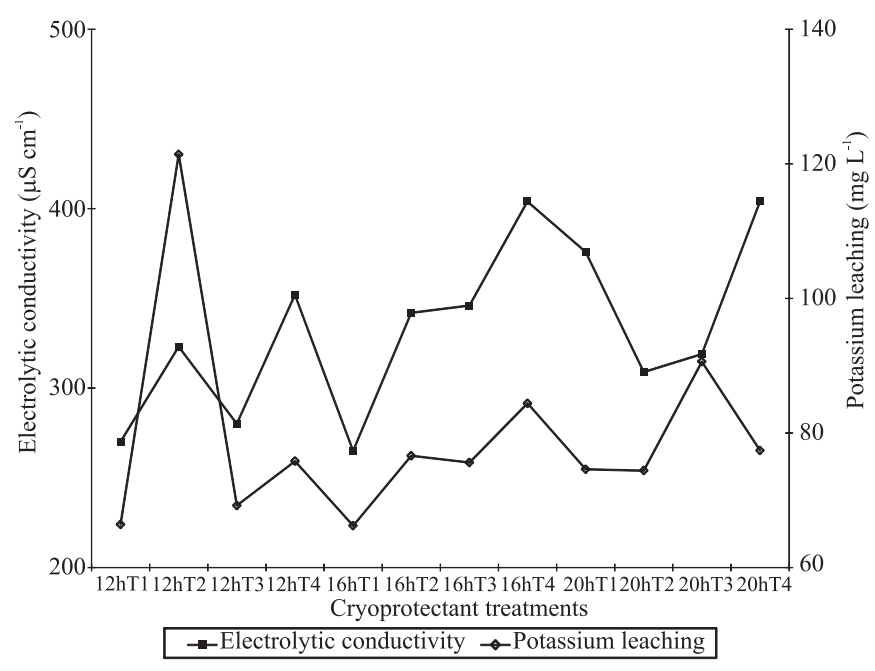

Figure 1. Electrolytic conductivity and potassium leaching in cryopreserved embryos of 'Anão Verde do Brasil de Jiqui' coconut in four cryoprotectant treatments combined with 12, 16 and 20 -hour incubation times. T1, $1.75 \mathrm{~mol} \mathrm{~L}^{-1}$ of sucrose $+15 \%$ glycerol; T2, $1.75 \mathrm{~mol} \mathrm{~L}^{-1}$ of glucose $+15 \%$ glycerol; T3, $1.75 \mathrm{~mol} \mathrm{~L}^{-1}$ of sucrose; and T4, $1.75 \mathrm{~mol} \mathrm{~L}^{-1}$ of glucose.

\section{Conclusions}

1. Ten embryos are adequate for sampling of electrolytic conductivity of cryopreserved or non-cryopreserved zygotic embryos of 'Anão Verde do Brasil de Jiqui' (AVeJBr) coconut.

2. A 4 to 8 hour incubation period is promising for analyzing electrolytic conductivity in noncryopreserved mature zygotic embryos of AVeJBr coconut.

3. Testing of electrolytic conductivity and potassium leaching can be used to determine the state of the cell membrane before and after cryopreservation of mature zygotic embryos of AVeJBr coconut.

\section{Acknowledgments}

To Empresa Brasileira de Pesquisa Agropecuária, to Conselho Nacional de Desenvolvimento Científico e Tecnológico, and to The International Coconut Genetic Resources Network, for financial support and for scholarship granted; and to the company H. Dantas for supplying the plant material.

\section{References}

ASSY-BAH, B.; ENGELMANN, F. Cryopreservation of mature embryos of coconut (Cocos nucifera L.) and subsequent regeneration of plantlets. CryoLetters, v.13, p.117-126, 1992.

BANDUPRIYA, H.D.D.; FERNANDO, S.C.; VERDEIL, J.-L.; MALAURIE, B. Effect of abscisic acid on survival and recovery of cryopreserved plumule explants of coconut (Cocos nucifera). Cocos, v.18, p.58-66, 2007.

BEST, B. Viability, cryoprotectant toxicity and chilling injury in cryonics. Toronto: Cryonics, 2010. 21p. Available at: $<$ http://www. benbest.com/cryonics/viable.html $>$. Accessed on: 18 Apr. 2010.

CROWE, J.H.; CROWE, L.M.; CARPENTER, J.F.; RUDOLPH, A.S.; WISTROM, C.A.; SPARGO, B.J.; ANCHORDOGUY, T.J. Interactions of sugars with membranes. Biochimica et Biophysica Acta, v.947, p.367-384, 1988.

EEUWENS, C.J. Mineral requirements for growth and callus initiation of tissue explants excised from mature coconut palms (Cocos nucifera) and cultured in vitro. Physiologia Plantarum, v.36, p.23-28, 1976.

HORNUNG, R.; DOMAS, R.; LYNCH, P.T. Cryopreservation of plumular explants of coconut (Cocos nucifera L.) to support programmes for mass clonal propagation through somatic embryogenesis. CryoLetters, v.22, p.211-220, 2001.

HORWITZ, W. (Ed.). Official methods of analysis of AOAC International. $18^{\text {th }}$ ed. Gaithersburg: AOAC International, 2005. $1170 \mathrm{p}$.

KARUN, A.; SAJINI, K.K.; KUMARAN, P.M.; SAMSUDHEEN, K. Cryopreservation of coconut (Cocos nucifera L.) pollen. Journal of Plantation Crops, v.34, p.568-571, 2006.

KARUN, A.; SAJINI, K.K.; PARTHASARATHY, V.A. Cryopreservation of mature coconut zygotic embryos by desiccation method. Cord, v.21, p.13-19, 2005.

MALAURIE, B.; BANDUPRIYA, H.D.D.; FERNANDO, S.C.; VERDEIL, J.-L. Optimisation du procédé de cryoconservation de la plumule de cocotier. Les Actes du Bureau des Ressources Génétiques, v.6, p.449-468, 2006.

MALAURIE, B.; TREGEAR, J.N.; N'NAN, O.; BANDUPRIYA, H.D.D.; BORGES, M.; VERDEIL, J.-L. Cryopreservation as a tool for the management of coconut germplasm. Acta Horticulturae, v.908, p.461-466, 2011.

MARTINS, C.C.; NAKAGAWA, J.; BOVI, M.L.A. Avaliação da qualidade fisiológica de sementes de açaí. Revista Brasileira de Fruticultura, v.31, p.231-235, 2009. 
N'NAN, O.; HOCHER V.; VERDEIL, J.-L.; KONAN, J.L.; BALO, K.; MONDEIL, F.; MALAURIE, B. Cryopreservation by encapsulation-dehydration of plumules of coconut (Cocos nucifera L.). CryoLetters, v.29, p.339-350, 2008.

REED, B.M. Plant cryopreservation: a practical guide. New York: Springer, 2008. 513p.

SAJINI, K.K.; KARUN, A.; KUMARAN, P.M. Cryopreservation of coconut (Cocos nucifera L.) zygotic embryos after pre-growth desiccation. Journal of Plantation Crops, v.34, p.576-581, 2006.

SANTOS, I.R.I. Criopreservação: potencial e perspectivas para a conservação de germoplasma vegetal. Revista Brasileira de Fisiologia Vegetal, v.12, p.70-84, 2000.

SANTOS, I.R.I.; SALOMÃO, A.N. Criopreservação de germoplasma vegetal. In: NASS, L.L. (Ed.). Recursos genéticos vegetais. Brasília: Embrapa Recursos Genéticos e Biotecnologia, 2007. p.545-573.

SISUNANDAR, R.A.; TURQUAY, P.; SAMOSIR, Y.; ADKINS, S.W. Cryopreservation of coconut (Cocos nucifera L.) zygotic embryos does not induce morphological, cytological or molecular changes in recovered seedlings. Planta, v.232, p.435-447, 2010.

SOUZA, L.A. de; CARVALHO, M.L.M. de; KATAOKA, V.Y.; OLIVEIRA, J.A. de. Teste de condutividade elétrica para avaliação da qualidade fisiológica de sementes de mamona. Revista Brasileira de Sementes, v.31, p.60-67, 2009.

VANZOLINI, S.; NAKAGAWA, J. Teste de condutividade elétrica em sementes de amendoim: efeitos de temperatura e de período de embebição. Revista Brasileira de Sementes, v.21, p.41-45, 1999.

VIEIRA, R.D. Teste de condutividade elétrica. In: VIEIRA, R.D.; CARVALHO, N.M. de. Testes de vigor em sementes. Jaboticabal: FUNEP, 1994. p.103-132.

$\overline{\text { Received on September 6, } 2011 \text { and accepted on December 17, } 2011}$ 